\title{
FEATURE Understanding opportunities and increasing implementation of climate friendly conservation
}

\author{
Ryan Stockwell and Eliav Bitan
}

A $\mathrm{t}$ the 2011 Annual Meeting of the Soil and Water Conservation Society, the Executive Director Jim Gulliford announced a new Position Statement on Climate Change and Soil and Water Conservation: "The Soil and Water Conservation Society finds that soil and water conservation practices can play a major role in the mitigation of agriculture's contribution to greenhouse gas emissions and adaptation to changes in seasonal precipitation and temperature patterns" (SWCS 2011). The National Wildlife Federation agreed with this position in the recent publication, Future Friendly Farming: Seven Agricultural Practices to Sustain People and the Environment (Stockwell and Bitan 2011). We found that the seven practices discussed in this publication also improve farmer profitability thanks to modern tools and knowledge (Stockwell and Bitan 2011).

Adoption of these and other soil and water conservation practices is in relatively early phases. Early innovators have begun incorporating these practices, but going from minimal adoption rates to broad or diffuse implementation will require additional information to not only answer farmers' questions, but to give them the information and encouragement to implement these practices. This article shares the experience of four early adopters of innovative practices. We hope these stories will help answer every farmer's first question about conservation practices: "How does the practice work and how would it work on my farm?" Each of these farmers increased their operations' profitability. We hope these stories and research prove valuable for farmers, government agency staff, researchers, and others as we work together to increase the adoption of future friendly farming practices.

Ryan Stockwell is agriculture manager and Eliav Bitan is agriculture advisor at the National Advocacy Center, National Wildlife Federation, Washington, DC.

\section{COVER CROPS}

Though cover crops are not widely used, they have remarkable potential to increase farmer profit while addressing climate change. Cover crops may be planted between rows of commodity crops or during the nongrowing season to protect the soil from wind and soil erosion, reduce nutrient loss to water, and provide nutrients to subsequent commodity crops. In our two case studies cover crops increased farm profitability by US $\$ 116$ and US $\$ 333$ $\mathrm{ha}^{-1}$ (US\$47 and US\$135 $\mathrm{ac}^{-1}$ ). Most of the revenue from cover crops came from their grazing value, at US $\$ 210$ and US $\$ 274 \mathrm{ha}^{-1}$ (US\$85 and US $\$ 111 \mathrm{ac}^{-1}$ ), but in one case herbicide costs were reduced by US $\$ 69$ $\mathrm{ha}^{-1}$ (US\$27.95 $\mathrm{ac}^{-1}$ ). In that case, the yield of the crop following the cover crop was increased, for an additional revenue value of US\$61.00 ha $\mathrm{ha}^{-1}$ (US\$24.70 $\mathrm{ac}^{-1}$ ). The farmer hypothesized that his use of a cover crop mixture including eight different species resulted in the weed suppression and increased yields. Similar results have been reproduced on other farms (Clark 2007).

Tom Boelter farms corn (Zea mays L.), soybeans (Glycine max L.), hay, and beef in the Root River Watershed of southeast Minnesota. Boelter recently added cereal rye (Secale cereal L.) as a cover crop to hold onto nutrients, improve soil health, and increase overall farm profitability. $\mathrm{He}$ seeded cereal rye into standing soybeans before harvest to capture nutrients more effectively. Boelter grazed the cereal rye after soybean harvest in the fall and again in the spring. He was then able to plant corn into the grazed and terminated cereal rye. Boelter maintained his commodity yields while increasing the grazing capacity of his lands. The cereal rye cover crop prevented soil erosion and absorbed and retained nutrients for the corn that would have otherwise found their way into the Mississippi River and Gulf of Mexico. Cover crops will be particularly useful as climate change causes increased frequency of heavy rainfall events, which can lead to more dramatic soil and nutrient loss.
While a cover crop grows, it uses photosynthesis to remove carbon dioxide $\left(\mathrm{CO}_{2}\right)$ from the atmosphere. The cover crop allocates about half of that carbon (C) to build its root system and feed soil biota, which help provide nutrients. The remaining $\mathrm{C}$ makes up the above-ground biomass of the plant. The carbon stored in soil and roots can stay below ground for hundreds or thousands of years, reducing greenhouse gases in the atmosphere. A review of the Minnesota literature found that winter cover crops such as those that Boelter used sequester an average of 1.48 $\mathrm{t} \mathrm{ha}^{-1}$ (0.6 th ac $\mathrm{ac}^{-1}$ ) of $\mathrm{CO}_{2}$ (Anderson and Beduhn 2008). With the potential for wide implementation of cover crops on over 40 million ha (100 million ac) across the United States, cover crops could play a significant role in reducing total emissions while at the same time helping to maintain or increase farm production in the midst of climate change.

\section{IMPROVED GRAZING MANAGEMENT}

Improvements in grazing management, such as increased plant diversity and animal rotations, lead to greater producer profitability, as well as soil, water, and climate benefits. Incorporating plant species native to a region can help maximize plant productivity. These practices reduce weed prevalence and increase water infiltration by minimizing the amount of uncovered soil. Moreover, a broad mix of plants improves ecosystem stability by reducing the dependence on any one species. More diverse species mixes coupled with more frequent rotations improve forage quality and increase the animal carrying capacity of the land. Importantly, through pasture and grassland management, forage production is less susceptible to reduced production caused by drought - an increasing reality for many regions under climate change.

Kelly Bonney raises beef in Quay County, New Mexico, on a ranch that has been in the family for over 100 years. Bonney implemented rotational grazing in order to more effectively manage the 
health of the soil and grass that support the ranch. Bonney carefully redesigned the grazing layout to decrease paddock size and increase the number of paddocks, while considering water availability and ease of movement between paddocks. Making this switch shortened the grazing period on each paddock and increased the recovery time. This resulted in improved paddock recovery and a net increase in carrying capacity from 1.63 to 3.09 animals $100 \mathrm{ha}^{-1}$ (0.66 to 1.25 animals 100 $\left.\mathrm{ac}^{-1}\right)$. Similar ranches implementing rotational grazing have recorded sequestration rates of $3.7 \mathrm{t} \mathrm{ha}^{-1} \mathrm{y}^{-1}\left(1.65 \mathrm{tn} \mathrm{ac}^{-1} \mathrm{yr}^{-1}\right)$ of $\mathrm{CO}_{2}$ above sequestration rates of continuous grazing (Morgan et al. 2010). At these rates, implementing mob grazing on the 166 million ha (410 million ac) of pasture or grazing land across the United States can have a significant impact in annual $\mathrm{C}$ emissions.

\section{MANURE DIGESTERS}

For livestock producers, managing animal manure is becoming a growing problem as farm size increases. Increasing the amount of manure concentrated in one location leads to higher transportation and storage costs, as well as greater risks associated with manure management. Applying waste to farm fields at higher rates dramatically increases the threat of introducing bacteria and nutrients into nearby waters or causing fish kills resulting from oxygen depletion.

Anaerobic digesters can improve farmer's profitability while providing soil, water, and climate change benefits. They work by heating manure, enabling bacteria to break down the animal waste into methane gas and a stable, inert material called digestate. The methane is then collected, cleaned, and burned to produce electricity and heat. By using or marketing the electricity, heat, and digestate produced by an anaerobic digester, farmers develop income streams or develop on-farm sources to replace expensive off-farm inputs.

Five Star Dairy, located near Elk Mound, Wisconsin, is co-owned and operated by Lee Jensen. With 900 head of dairy cows, Jensen sought to implement a system that improved effectiveness of handling and treating manure. Six years ago, Jensen added an anaerobic digester to the farm. High up-front costs necessitated creative partnerships to share the investment. Jensen partnered with the local electric co-op and a digester construction and management firm on the project. This partnership not only distributed the costs, but brought in valuable knowledge to the project. As a result, Jensen will experience a return on investment of around six years on a project with an expected life of around 25 years. A couple of years after completing the digester, Jensen added a lagoon cover. This cover not only captures residual methane for flaring, but it also prevents rainwater from entering the lagoon, reducing manure application costs (Stockwell and Bitan 2011).

Under normal conditions, bacteria such as E. coli, Cryptosporidium, and Salmonella can survive for over a year in manure. When manure reaches surface water, the attached bacteria spread quickly and can enter drinking water or irrigation supplies. When animal waste is heated for an extended period, pathogens that typically survive and thrive in ambient temperatures expire (Sobsey et al. 2006). Manure digestion reduces the deposition of pathogens into waterways from field-applied manure, providing an added benefit to society.

Studies show an increase of over 25\% of soluble or available nitrogen due to the digestion process (Smith et al. n.d.). This improvement in nutrient delivery from manure can mean fewer nutrients entering waterways as plants can more quickly absorb the nutrients. It also means farmers can cut back on fertilizer applications, reducing costs to farmers while further reducing the threat of nutrient loss to waterways, all the while maintaining yield and profit.

Finally, anaerobic digesters offer climate benefits. Manure storage currently emits roughly $7 \%$ of all domestic methane emissions. Digesters can play a role in reducing those direct emissions. Anaerobic digestion can eliminate over 6.46 t $(7.13$ tn) of $\mathrm{CO}_{2 \mathrm{e}}$ emissions per dairy cow per year (Martin 2003). Additionally, digesters can help reduce nitrous oxide emissions from land-applied manure and fertilizer by aiding the nutrient absorption process and reducing the need for fertilizer use for farmers. Finally, digesters that produce electricity and thermal energy offset or reduce the demand for fossil fuel-based sources and the greenhouse gas emissions those sources emit, while at the same time providing steady new income streams for farmers.

\section{INTERMITTENT RICE FLOODING}

Rice (Oryza sativa) provides about 20\% of global food for human consumption (Smith 1998). Traditional agronomic techniques require a long period of flooding. During flooded conditions, soils produce methane, a potent greenhouse gas. Rice production alone accounts for about $2 \%$ of global greenhouse gas emissions (WRI 2008). In the United States, rice farmers usually have to pump water to rice fields, accounting for a sizeable cost of rice production. Reducing the flooding period in rice production while maintaining yields would not only reduce greenhouse gas emissions, but also reduce costs to farmers. In addition, intermittent flooding would also provide rice farmers with more adaptability to fluctuations in precipitation.

Earl Kline farms rice, soybeans, and corn near Cleveland, Mississippi. With information and technical assistance from Mississippi State University agronomists, Kline implemented an intermittent flooding approach to his rice acres. Reducing water use cut Kline's pumping costs by $30 \%$, saving US $\$ 37 \mathrm{ha}^{-1}$ (US $\$ 15 \mathrm{ac}^{-1}$ ), while maintaining rice yield and quality. Reducing water use also reduced runoff of nutrients and pesticides. In addition, greenhouse gas emissions were reduced by a total of $0.92 \mathrm{t} \mathrm{ha}^{-1}\left(1.01 \mathrm{tn} \mathrm{ac}^{-1}\right)$ of $\mathrm{CO}_{2 \mathrm{e}}$ through reduced methane emissions and reduced fuel used for pumping water (Stockwell and Bitan 2011). Under intermittent flooding, farmers make more efficient use of both rainwater and pumped water.

\section{CONCLUSION}

Unfortunately, barriers exist that prevent landowners from adopting these futurefriendly farming practices. For many farmers, a lack of awareness of or familiarity with these practices is a simple and obvious barrier. Even farmers who have invested the time to learn about new prac- 
tices face barriers precluding them from making the actual leap in altering or abandoning their current farming techniques. Farming is a business with considerable capital investment. Farmers devote substantial amounts of money in equipment designed for specific tasks. Transitioning to new practices often requires different machinery. Selling unneeded machinery, finding the right new equipment, and accomplishing both without losing too much money in the process can be daunting.

Additionally, farmers who adopt the future-friendly farming techniques described above may not experience benefits for a few years. For example, improving soil health through cover crops often takes a few years to allow the soil to build up $\mathrm{C}$ and soil organic matter and reduce bulk density, which all eventually contribute to healthier, more productive soil. In the meantime, farmers incur the transition costs. Farmers who have made the transition to no-till from conventional till have noted that there is roughly a threeyear transition during which yield suffers. After the transition, when the soil fertility has developed through more natural systems, yield levels return to and frequently exceed yields obtained previously using conventional till. Even if these practices offer the potential for improved profitability down the road, the combination of up-front costs with delayed benefits can stand as an imposing barrier.

The innovative farmers described in this paper are an example and source of guidance for other farmers making land and resource management decisions. Experiences and stories of early innovators can be valuable tools in educating about new techniques that can mitigate greenhouse gas emissions while also highlighting practices that will help farmers succeed in a changing climate filled with more extreme weather patterns. Through these techniques, farmers can play a significant role in reducing greenhouse gas emissions, address other environmental issues, and improve long-term profitability.

\section{REFERENCES}

Anderson, J., and R. Beduhn. 2008. The Potential for Terrestrial Carbon Sequestration in Minnesota:A Report to the Department of Natural Resources from the Minnesota Terrestrial Carbon Sequestration Initiative. St. Paul, MN: University of Minnesota.

Clark, A. 2007. Managing Cover Crops Profitably. 3rd ed. Beltsville, MD: Sustainable Agriculture Network.

Morgan, J.A., R. Follett, L.H. Allen Jr., S. Del Grosso, J. Derner, F. Dijikstra, A. Franzluebbers, R. Fry, K. Paustian, and M.M. Schoeneberger 2010. Carbon sequestration in agricultural lands of the United States. Journal of Soil and Water Conservation 65:6A-13A

Martin, Jr., John H. 2003. A Comparison of Dairy Cattle Manure Management with and without Anaerobic Digestion and Biogas Utilization: http://renewwisconsin.org/biogas/AD/AA\%20 Dairy\%20NY\%20Study.pdf.

Smith, B. 1998. The Emergence of Agriculture. New York: Scientific American Library.

Smith, K.A., W.A. Jeffrey, J.P. Metcalfe, A.H Sinclair and J.R. Williamsl. n.d. Nutrient value of digestate from farm-based biogas plants. http://www.ramiran.net/ramiran2010/docs/ Ramiran2010_0171_final.pdf.

Sobsey, M.D., L.A. Khatib,V.R. Hill, E. Alocilja, and S Pillai. 2006. Pathogens in animal wastes and the impacts of waste management practices on their survival, transport and fate. In Animal Agriculture and the Environment: National Center for Manure and Animal Waste Management White Papers, eds. J. M. Rice, D. F. Caldwell, F. J. Humenik, 609-666. St. Joseph, MI: American Society of Agricultural and Biological Engineers. Stockwell, R., and E. Bitan. 2011. Future Friendly Farming: Seven Agricultural Practices to Sustain People and the Environment. http:// www.nwf.org/ /media/PDFs/Wildlife/ FutureFriendlyFarmingReport.ashx.

SWCS (Soil and Water Conservation Society). 2011 Position Statement on Climate Change and Soil and Water Conservation. http://www.swcs.org/ documents/filelibrary/climate/SWCS_Climate_ Position_Statement_751_46C025478C4CA.pdf. WRI (World Resources Institute). 2008. World Greenhouse Gas Emissions: 2000. http:// www.wri.org/chart/world-greenhousegas-emissions-2000. 